\title{
Phenolic compounds, antimicrobial activity, cytotoxicity and identification of phytochemicals present in Inga marginata Willd seeds
}

\author{
Compostos fenólicos, atividade antimicrobiana, citotoxicidade e \\ identificação de fitoquímicos presentes em sementes de Inga \\ marginata Willd
}

\author{
Déborah Cristina Barcelos Flores ${ }^{(\mathbb{D})}$, Caroline Pagnossim Boeira' ${ }^{(1)}$, \\ Clarice Madalena Bueno Rolim "II(1), Daniele Rubert Nogueira Librelotto'"I(1), \\ Frederico Luiz Reis"(1), Liziane Maria Barassuol Morandini"(i), \\ Ademir Farias Morel"(i), Claudia Severo da Rosa'(i) \\ ' Federal University of Santa Maria, Department of Technology in Food Science, Santa Maria, RS, Brazil \\ "Federal University of Santa Maria, Chemistry Department, Santa Maria, RS, Brazil \\ III Federal University of Santa Maria, Industrial Pharmacy Department, Santa Maria, RS, Brazil
}

\begin{abstract}
Brazil has an invaluable source of plants and fruits rich in phenolic compounds important to health, many of which have yet to be investigated. Inga marginata Willd is a fruit that can be found throughout Brazil, and its seeds are rich in phenolic compounds and antimicrobial activity, thus making their extraction and characterization highly relevant. This study aimed to determine the total phenolic compounds, antioxidant capacity, antibacterial and antifungal activities, cytotoxicity evaluation, and characterize the phytochemical compounds present in the extract. This study demonstrated that extraction by agitation at $30^{\circ} \mathrm{C}$ presented the highest yield of total phenolic compounds $\left(48.23 \mathrm{mg} \mathrm{GAE} \mathrm{g}^{-1}\right)$, antioxidant capacity (40.34 mg TEAC g $\left.{ }^{-1}\right)$, and $\mathrm{IC}_{50}\left(2.60 \mathrm{mg} \mathrm{mL}^{-1}\right)$. The extracts at 30 and $60{ }^{\circ} \mathrm{C}$ inhibited all microorganisms tested, and the temperature of $30^{\circ} \mathrm{C}$ acted as a bactericide and fungicide at low concentrations. Ten phytochemical compounds were found, mainly being antioxidants and antimicrobials. The cytotoxicity assays showed that Inga marginata seeds do not present cellular cytotoxicity up to the concentration of $250 \mu \mathrm{g} \mathrm{mL}-1$, maintaining cell viability above $90 \%$.
\end{abstract}

Keywords: Total phenolics; Extraction; Identification by ESI-ToF-MS; Toxicity; Antimicrobial activity 


\section{RESUMO}

O Brasil possui uma fonte inestimável de plantas e frutos ricos em compostos fenólicos importantes à saúde, muitos dos quais ainda não foram investigados. O Inga marginata Willd é um fruto que pode ser encontrado em todo o território brasileiro, e suas sementes são ricas em compostos fenólicos e atividade antimicrobiana, tornando sua extração e caracterização altamente relevantes. Este estudo teve como objetivo, determinar os compostos fenólicos totais, a capacidade antioxidante, atividades antibacteriana e antifúngica, avaliação da citotoxicidade e caracterização dos compostos fitoquímicos presentes no extrato. $\mathrm{O}$ estudo demonstrou que a extração por agitação a $30^{\circ} \mathrm{C}$, apresentou maior rendimento de compostos fenólicos totais (48.23 $\left.\mathrm{mg} \mathrm{GAE} \mathrm{g}^{-1}\right)$, capacidade antioxidante (40.34 $\left.\mathrm{mg} \mathrm{TEAC} \mathrm{g}^{-1}\right)$, e IC 50 (2.60 $\mathrm{mg} \mathrm{mL}{ }^{-1}$ ). Os extratos a 30 e $60{ }^{\circ} \mathrm{C}$ da semente de Ingá inibiram todos os micro-organismos testados, sendo que a temperatura de $30^{\circ} \mathrm{C}$ atuou como bactericida e fungicida em baixas concentrações. Foram encontrados dez compostos fitoquímicos, principalmente antioxidantes e antimicrobianos. Os ensaios de citotoxicidade mostraram que a semente de Inga marginata não apresentaram citotoxicidade celular até a concentração de $250 \mu \mathrm{g} \mathrm{mL}^{-1}$, mantendo a viabilidade celular acima de $90 \%$.

Palavras-chave: Fenólicos totais; Extração; Identificação por ESI-ToF-MS; Toxicidade; Atividade antimicrobiana

\section{INTRODUCTION}

Brazil has a rich biodiversity, and the Amazon rainforest is an invaluable source of plants rich in bioactive compounds. With the growing search for a natural and healthy life, consumer interest in natural bioactive compounds has increased (SILVA; ROGEZ; LARONDELLE, 2007). Bioactive compounds constitute the majority of active ingredients present in plant parts, provide many benefits to human health, and act in food preservation (HARUNA; YAHAYA, 2021). The genus Inga belongs to the Fabaceae family, and plants of this family can be found throughout Brazil and South and Central America. The Inga fruit of the species Inga marginata Willd is popularly known as "Ingá-mirim" or "Ingá feijão" characterized as long yellow-green pods containing 2 to 15 seeds of green color and flaky-sweet white flesh (LIMA; SANTOS; LA PORTA, 2018; POSSETE; RODRIGUES, 2010). Previous studies with the genus Inga have shown that phenolic compounds are present in the leaves of Inga umbellifera and Inga goldmani (LOKVAM; COLEY; KURSAR, 2004), in addition to Inga edulis leaves (NASCIMENTO; SOBRINHO; SOUZA; De SOUZA; SOUSA, 2021). From the leaves and bark of the species Inga edulis, phenolic compounds and flavonoids have also been isolated and their antioxidant capacity evaluated (DIAS; SOUZA; 
ROGEZ, 2010; TCHUENMOGNE et al., 2013). In fruit and vegetable residues, for example, seeds are commonly discarded despite having excellent nutritional and functional characteristics. Studies have suggested that antioxidants in fruits and their residues may reduce the risk of cancer and related mortality. In addition, the antioxidant potential and functional properties have been investigated, especially to replace the use of synthetic antioxidants in food products that may represent a health risk (SUHAIL et al., 2012). Phenolic compounds are involved in the defense mechanism of plants and protect them against ultraviolet radiation and pathogens (DAl; MUMPER, 2010). Various biological effects have already been studied, including antioxidant, anti-inflammatory, antibacterial, and antiviral activities (TANASE et al., 2019). This demonstrates that numerous studies can be conducted with this class of compounds and underlines the importance of further research to discover and identify new compounds. Phenolic compounds are attractive due to their antioxidant activity that reduces oxidative stress and prevents or delays oxidation by eliminating free radicals, both in the human body and food preservation (KOOLEN; SILVA; GOZZO; SOUZA; SOUZA, 2013).

The use of antioxidants derived from natural resources has been gaining attention due to their health benefits, including preventing cardiovascular diseases, inflammation, and aging-related disorders (AQIL et al., 2012). In addition, the use of these plant extracts has become a promising alternative for preserving processed foods, reducing reliance on other chemical additives, and prolonging the shelf life of products (MUNIR et al., 2018). The search for substances that can help develop new drugs has increased the interest of the food industry and research institutions in natural products. In this sense, preliminary tests allow researchers to make inferences about the toxicity of such products. One model of toxicity evaluation that is gaining strength is cytotoxicity, which uses mammalian cells and evaluates the damage caused to cells, cell colony formation, and cell viability. Cell cultures have become a much-appreciated model because they are reproducible, 
sensitive, fast, and do not require animal testing (BEDNARCZUK; VERDAM; MIGUEL; MIGUEL, 2010; ROGERO; LUGÃO; IKEDA; CRUZ, 2003).

Given the above, this study aims to determine the phenolic compounds, antioxidant capacity by in vitro methods, evaluate antibacterial and antifungal activities, characterize the phytochemical compounds by electrospray ionization time-of-flight mass spectrometry (ESI-ToF-MS) in the extract, and the cytotoxicity of Inga marginata Willd seeds.

\section{MATERIALS AND METHODS}

\subsection{Fruit collection and sample preparation}

Inga marginata Willd fruits were collected in the Federal University of Santa Maria, Santa Maria $\left(-29.7215^{\circ} \mathrm{S}\right.$ and $\left.53.7184^{\circ} \mathrm{W}\right)$, southern Brazil. The fruits were opened manually and the seeds were reserved. Pre-drying was performed at $45 \pm$ $5{ }^{\circ} \mathrm{C}$ for $48 \mathrm{~h}$ in a forced air circulation oven (Marconi, MA-035/100, Piracicaba, Brazil) according to Djikeng et al., (2018), with modifications. After drying, the seeds were ground in a knife mill (Willy, SL-31), passed through a 20-mesh sieve, and stored at $-18{ }^{\circ} \mathrm{C}$. The species Inga marginata Willd was registered under number ACD526F in the National System for the Management of Genetic Heritage and Associated Traditional Knowledge (SISGEN).

\subsection{Obtaining the hydroalcoholic extracts}

Following the method of Victório, Lage, and Kuster (2010) with modifications, the extracts were obtained through solid-liquid extraction using $2 \mathrm{~g}$ of pre-dried and ground sample, and $40 \mathrm{~mL}$ of $70 \%$ ethanol $(1: 10 ; \mathrm{p} / \mathrm{v})$ was added to a beaker. The extraction time was set to $25 \mathrm{~min}$ and, and just the temperatures of 30 and 60 ${ }^{\circ} \mathrm{C}$ were used according to Piovesan et al., (2017). The samples were then subjected to constant stirring with a mechanical stirrer (Marconi, MA-039, Piracicaba, Brazil). 
After extraction, each extract containing the solvent and ground material mixture was subjected to centrifugation (Centrilab, SH-120) at $3000 \mathrm{rpm}$ for $10 \mathrm{~min}$ and filtered. The volume was adjusted and the samples were then stored in amber flasks in a freezer $\left(-18^{\circ} \mathrm{C}\right)$.

\subsection{Total phenolic content}

The total phenolic compounds (TPC) were determined by the Folin-Ciocalteu spectrophotometric method of Roesler, Malta, Carrasco, Holanda, Souza, and Pastore (2007), with modifications. The absorbance was read at $760 \mathrm{~nm}$ in a spectrophotometer (Biospectro, SP-220, São Paulo, Brazil). A standard curve was performed for quantification ( $\left.y=0.0012 x+0.021 R^{2}=0.9953\right)$ using gallic acid as a positive control, and the results were expressed as milligrams of gallic acid per gram of dry sample (mg GAE $\left.\mathrm{g}^{-1}\right)$.

\subsection{Radical scavenging activity determination}

For the antioxidant assays, the radical scavenging activity of the extracts was determined by 2,2-diphenyl-1-picrylhydrazyl (DPPH) (Brand-Williams, Cuvelier, and Berset, 1995). Readings were performed in a spectrophotometer (Biospectro, SP220) at a wavelength of $517 \mathrm{~nm}$. The free radical scavenging capacity was calculated according to Equation 1 and expressed as percent inhibition of radical oxidation. The scavenging activity was measured by decreasing the absorbance of the samples compared to the DPPH standard.

$$
\% D P P H \text { Sca }=\left[\frac{(\text { Abs samp AbsNC })}{(\text { AbsPC }- \text { AbsNC) }}\right] \times 100
$$

Where \%DPPH Sca is the percentage of inhibited DPPH, Abs samp is the absorbance of the sample, Abs $\mathrm{NC}_{\mathrm{N}}$ is the negative control, and AbsPC is the positive control of the measured calibrated curves. To determine the $\mathrm{IC}_{50}$, the equation of 
the line obtained from the absorbance values (AA\%) of the increasing concentrations of the samples was used, replacing the value of $Y$ by 50 , and obtaining the value of $X$ as the concentration of the sample with the capacity to reduce the DPPH by 50\%. The result is expressed as Trolox Equivalent Antioxidant Capacity $\left(\mu \mathrm{mol}\right.$ TEAC $\left.^{-1}\right)$.

\subsection{Antibacterial activity and antifungal activity}

Standard strains from the American Type Culture Collection (ATCC) were used for microbiological assays. For the extracts obtained at 30 and $60{ }^{\circ} \mathrm{C}$, the antibacterial and antifungal activities were evaluated by the broth microdilution method, and the 96-well plate analysis was performed by spectrophotometry at a wavelength of $620 \mathrm{~nm}$ (NCCLS, 2017, 2018). A collection of twenty-four microorganisms was used, including five Gram-positive bacteria: Staphylococcus aureus (ATCC 25923), Bacillus cereus (ATCC 11778), Enterococcus fecalis (ATCC 19433), Enterococcus ssp. (ATCC 6589), and Bacillus subtilis (ATCC 19659), and ten Gramnegative bacteria: Salmonella enteric serovar Typhimurium (ATCC 14028), Escherichia coli (ATCC 25922), Shigella sonnei (ATCC 25931), Enterobacter aerogenes (ATCC 13048), Salmonella enteritidis (ATCC 13076), Shigella flexneri (ATCC 12022), Pseudomonas aeroginosa (ATCC 27853), Morganella morganii (ATCC 25829), Proteus mirabilis (ATCC 25933), and Klebsiella pneumoniae (clinical isolate). Nine yeasts were also used: Candida parapsilosis (ATCC 22019), Candida tropicalis (ATCC 750), Candida albicans (ATCC 10231), Candida glabrata (ATCC 2001), Candida dubliniensis (ATCC MYA-577), Candida krusei (ATCC 6258), Cryptococcus gatti (ATCC 56990), Cryptococcus neoformans (ATCC 28952), and Saccharomyces cerevisiae (ATCC 2601). The minimum inhibitory concentration (MIC) was determined in 96-well culture plates by the microdilution method using a microorganism suspension at a density of 105 CFU $\mathrm{mL}^{-1}$ with Casein Soy Broth incubated for $24 \mathrm{~h}$ at $37^{\circ} \mathrm{C}$ for bacteria, and Sabouraud Broth incubated for $48 \mathrm{~h} 25{ }^{\circ} \mathrm{C}$ for the yeast (NCCLS, 2017, 2018). Cultures that 
showed no growth were used to re-inoculate the plates (Casein Soy Broth and Sabouraud) and determine the minimum lethal concentration (MLC). The appropriate blanks were assayed simultaneously, and all samples were tested in triplicate. The results are expressed as a function of MIC and MLC.

\subsection{Inga seed extract characterization by ESI-ToF MS}

The extract at the temperature that obtained the highest phenolic and antioxidant content from the Inga seed was submitted to characterization by electrospray ionization time-of-flight mass spectrometry (ESI-ToF MS; Xevo G2 Qtof, Waters Inc., Milford, USA). Then, $50 \mu \mathrm{L}$ of the extract was used, which was previously filtered through a syringe with a PTFE membrane (13 $\mathrm{mm} \times 0.22 \mu \mathrm{m})$ and then diluted in $2 \mathrm{~mL}$ of acetonitrile $(\mathrm{ACN}) / \mathrm{H}_{2} \mathrm{O}(1: 1)$ with $0.1 \%$ formic acid in positive mode (BIZZI et al., 2019). Moreover, in negative mode, the extract was solubilized in $2 \mathrm{~mL}$ of methanol and $50 \mu \mathrm{L}$ of ammonium hydroxide. Mass spectra were acquired from 50 to 1000 Dalton (Da), and detection by ESI-TOF MS was performed in positive ion and negative ion modes with a capillary voltage of $2.00 \mathrm{kV}$, cone voltage of $20 \mathrm{~V}$, and extractor cone voltage of $3.0 \mathrm{~V}$. The flow rates of the desolvation gas and gas cone were 500 and $10 \mathrm{~L} \mathrm{~h}^{-1}$, respectively. The desolvation temperature was set to $500{ }^{\circ} \mathrm{C}$ and the source temperature to $150{ }^{\circ} \mathrm{C}$. As for the negative ion mode, the capillary voltage was $2.5 \mathrm{kV}$, cone voltage was $40 \mathrm{~V}$, and the extractor cone voltage was $4.0 \mathrm{~V}$. The flow rates of the desolvation gas and gas cone were 200 and $10 \mathrm{~L} \mathrm{~h}^{-1}$, respectively. The desolvation temperature was set to $450^{\circ} \mathrm{C}$ and the source temperature to $150{ }^{\circ} \mathrm{C}$. System control and data acquisition were performed by using MassLynx V 4.1 software.

\subsection{Inga seed cytotoxicity}

The Inga marginata Willd seeds were freeze-dried and dissolved in $1 \mathrm{~mL}$ of phosphate-buffered saline (PBS) without dimethylsulfoxide (DMSO). Swiss albino 
mouse fibroblast cell line (3T3) cultured in Dulbecco's Modified Eagle Medium (DMEM) and supplemented with $10 \%(\mathrm{v} / \mathrm{v})$ fetal bovine serum (FBS) at $37^{\circ} \mathrm{C}$ and $5 \%$ $\mathrm{CO}_{2}$ was used. The cells were harvested using trypsin-EDTA when they reached a confluence of $80 \%$, and the samples were seeded in 96 -well plates at a density of 1 $\times 10^{5}$ cells $\mathrm{mL}^{-1}$ and incubated for $24 \mathrm{~h}$ under $5 \% \mathrm{CO}_{2}$ at $37{ }^{\circ} \mathrm{C}$. Afterward, the medium was replaced with $100 \mu \mathrm{L}$ of fresh medium supplemented with $5 \%(\mathrm{v} / \mathrm{v})$ FBS with the samples (concentration from 15.6 to $500 \mu \mathrm{g} \mathrm{mL}^{-1}$ ), the control cells (only the medium containing 5\% (v/v) FBS, the remaining cells were exposed to each treatment for $24 \mathrm{~h}$, after which the medium containing the samples was removed, and $100 \mu \mathrm{L}$ of MTT $\left(0.5 \mathrm{mg} \mathrm{mL}^{-1}\right)$ or NR dye $\left(50 \mu \mathrm{g} \mathrm{m}^{-1}\right)$ was added to each well. Then, the plates were incubated for $3 \mathrm{~h}$, the medium removed and single washing of the NRU assay wells carried out in PBS, followed by adding $100 \mu \mathrm{L}$ of DMSO (MTT assay). For the NRU assay, $100 \mu \mathrm{L}$ of a solution containing $50 \%$ absolute ethanol and $1 \%$ acetic acid in distilled water was added. After 10 min of stirring at room temperature, the absorbance of the solutions was measured at $550 \mathrm{~nm}$ using a microplate reader (Multiskan FC, Thermo Scientific, San Jose, CA, USA). The cytotoxic effects of the samples were evaluated by 2,5-diphenyl-3-(4,5-dimethyl-2thiazolyl) tetrazolium bromide (MTT) as described by Mossmann (1983) and by neutral red uptake (NRU) viability assay according to Borenfreund and Puerner (1985). The cytotoxicity of the sample was expressed as percent viability relative to untreated control cells (average of untreated cells adjusted at $100 \%$ viability). In terms of $\mathrm{IC}_{50}$ (concentration required for $50 \%$ cell death), it was calculated by adjusting the percentage of the cell survival curve against the sample concentrations.

\subsection{Statistical analysis}

All experiments were performed in triplicate, and the results were expressed as mean values and standard deviation (SD), submitted to analysis of variance 
(ANOVA) and Tukey's test with a significance level of 95\% $(p<0.05)$ using Statistica 10.0 software (Stat Soft, Inc., USA). For cytotoxicity analysis, the data were submitted to ANOVA, and the means were compared by Dunnet's test in multiple comparisons, considering there was a significant difference when a level of $p<0.05$ was reached through the GraphPad Prism 6.0 software.

\section{RESULTS AND DISCUSSION}

\subsection{Evaluation of total phenolic compound content, antioxidant capacity of Inga} seeds, and IC 50

The total phenolic content of the Inga seed extracts and radical scavenging activity are presented in Table 1.

Table 1 - Content of total phenolic compounds and radical scavenging activity (DPPH and IC $C_{50}$ )

\begin{tabular}{lccc}
\hline Temperature & Total phenolics $\left(\mathbf{m g ~ G A E ~ g}^{-1}\right)$ & DPPH $\left(\boldsymbol{\mu m o l ~ T E A C ~} \mathbf{~ g}^{-1}\right)$ & IC $_{\mathbf{5 0}}\left(\mathbf{m g ~ m L}^{-1}\right)$ \\
\hline $30^{\circ} \mathrm{C}$ & $48.23^{\mathrm{a}} \pm 1.90$ & $40.34^{\mathrm{a}} \pm 2.04$ & $2.60^{\mathrm{b}} \pm 1.48$ \\
$60^{\circ} \mathrm{C}$ & $36.89^{\mathrm{b}} \pm 2.49$ & $34.15^{\mathrm{b}} \pm 2.75$ & $3.80^{\mathrm{a}} \pm 1.97$ \\
\hline
\end{tabular}

Source: Authors (2021)

In where: Results are expressed as mean \pm SD. GAE = Gallic acid equivalent; DPPH = 2,2-diphenyl-1picrylhydrazyl. IC ${ }_{50}=$ inhibitory capacity. TEAC $=$ Trolox equivalent antioxidant capacity. Values expressed as mean \pm standard deviation with different letters on the same column indicating a significant difference $(p<0.05)$ by Tukey's test.

The extract obtained at $30{ }^{\circ} \mathrm{C}$ showed the highest total phenolic content (48.23 mg GAE $\mathrm{g}^{-1}$ ), which was statistically different from the temperature of $60^{\circ} \mathrm{C}$ (36.89 $\mathrm{mg} \mathrm{GAE} \mathrm{g}^{-1}$ ) (Figure 1A). Phenolic compounds are important to human health due to their high antioxidant activity and their effects against anti-inflammatory, cardiovascular, and neurodegenerative diseases, including cancer (SCALBERT; JOHNSON; SALTMARSH, 2005). 
Figure 1 - Yields of total phenolic compounds (A) and antioxidant capacity by the DPPH method (B) and inhibitory capacity $\left(\mathrm{IC}_{50}\right)(\mathrm{C})$ of Inga seed extracts obtained at 30 and $60^{\circ} \mathrm{C}$

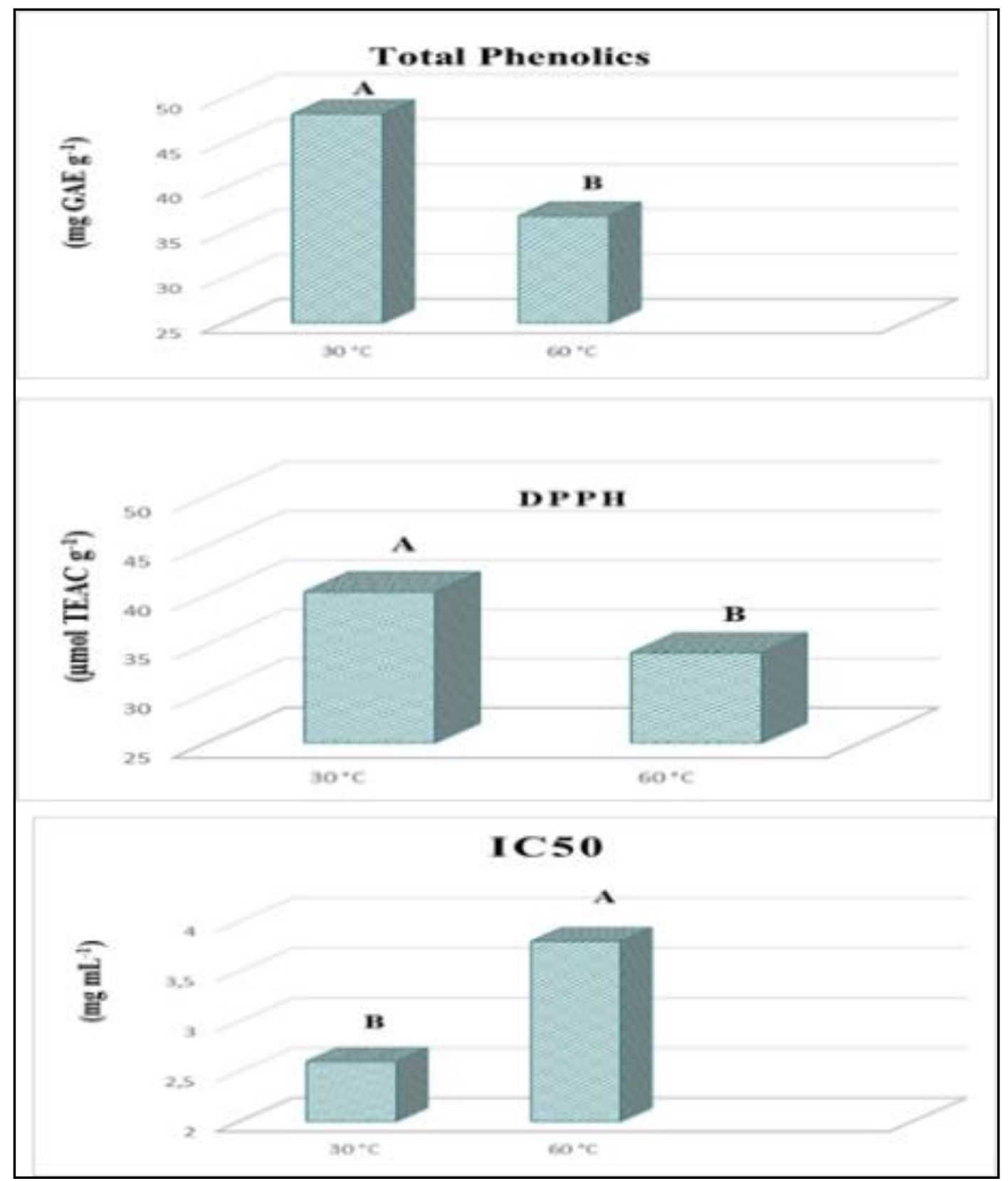

Source: Authors (2021)

The most proven mechanism of action of these compounds is eliminating free radicals, which reduces oxidative stress (SILVA; ROGEZ; LARONDELLE, 2007). Several external and internal factors can originate the degradation process of phenolic compounds, and temperature is the most important factor that promotes degradation reactions. During the extraction at the highest temperature, oxidative 
enzymes present in the sample are released during the extraction and promote degradation reactions (Liazid, Palma, Brigui, and Barroso, 2007). Mendoza, Martínez, Martínez, Barba, and De Ortiz (2016) found low phenolic compound content in Inga Paterno seeds $\left(0.55 \mathrm{mg} \mathrm{GAE} \mathrm{g}^{-1}\right)$, and this low content may be due to not using extraction parameters (e.g., temperature) and use of extracting solvents to obtain the phenolic compounds.

The antioxidant capacity at $30^{\circ} \mathrm{C}(40.34 \mu$ mol TEAC g-1 $)$ was statistically higher compared to the extract obtained at $60^{\circ} \mathrm{C}\left(34.15 \mu \mathrm{mol}\right.$ TEAC $\left.{ }^{-1}\right)$ (Table 1 and Figure 1B), which may be because the stability of the antioxidant compounds varies according to their composition and distribution in plants, fruits, or seeds. Some of these compounds are unstable at high temperatures, prone to oxidation, or thermolabile or volatile, thus decreasing the concentration of antioxidant compounds in the extracts (ALARA; ABDURAHMAN; UKAEGBU, 2021). Regarding the inhibitory capacity of the extract $\left(I C_{50}\right)$, the temperature of $30{ }^{\circ} \mathrm{C}\left(2.60 \mathrm{mg} \mathrm{mL}^{-1}\right)$ (Table 1 and Figure $1 \mathrm{C}$ ), was the one with the lowest IC 50 value, meaning the plant has high antioxidant power. The $\mathrm{IC}_{50}$ is a parameter used to determine the antioxidant potential of plants and demonstrates the amount of plant extract required to capture DPPH radicals by 50\% (NEGRELLE; GOMES, 2007).

\subsection{Antimicrobial activity of Inga seed extracts at 30 and $60^{\circ} \mathrm{C}$}

The antibacterial (Gram-positive and Gram-negative bacteria) and antifungal activity of the obtained extracts were analyzed (Tables 2 and 3). The MIC and MLC values of each extract were tested and compared to controls (antibiotics). 
Table 2 - Antibacterial activity (MIC and MLC in $\mu \mathrm{g} / \mathrm{mL}$ ) of the extracts obtained at 30 and 60 ${ }^{\circ} \mathrm{C}$ from the Inga marginata Willd seeds

\begin{tabular}{|c|c|c|c|c|c|c|c|c|}
\hline \multicolumn{5}{|c|}{ Gram-positive bacteria } & \multicolumn{4}{|c|}{ Sample } \\
\hline & \multicolumn{2}{|c|}{ Seed $30^{\circ} \mathrm{C}$} & \multicolumn{2}{|c|}{ Seed $60^{\circ} \mathrm{C}$} & \multicolumn{2}{|c|}{ Chloramphenicola $^{\mathrm{a}}$} & \multicolumn{2}{|c|}{ Ampicilian $^{a}$} \\
\hline & MIC & MLC & MIC & MLC & MIC & MLC & MIC & MLC \\
\hline Bs & 62.5 & 125 & 125 & 500 & 62.5 & 50 & 100 & 200 \\
\hline$B C$ & 62.5 & - & 62.5 & - & 3.12 & 12.5 & 200 & 200 \\
\hline Eph & 62.5 & - & 62.5 & - & 3.12 & 12.5 & 1.56 & 12.5 \\
\hline Sa & 31.2 & 500 & 62.5 & 250 & 1.56 & 6.25 & 200 & 200 \\
\hline \multicolumn{5}{|c|}{ Gram-negative bacteria } & \multicolumn{4}{|c|}{ Sample } \\
\hline St & 250 & - & 250 & - & 3.2 & 12.5 & 200 & 200 \\
\hline Sn & 125 & 500 & 125 & 500 & 1.56 & 12.5 & 3.12 & 100 \\
\hline$P m$ & 250 & - & 250 & - & 6.25 & 25 & 25 & 200 \\
\hline$E C$ & 250 & - & 250 & - & 3.12 & 100 & 200 & 200 \\
\hline$P a$ & 250 & - & 250 & - & 3.12 & 12.5 & 50 & 200 \\
\hline$S f$ & 62.5 & 500 & 62.5 & 500 & 1.56 & 3.12 & 12.5 & 200 \\
\hline Ss & 125 & - & 125 & - & 1.56 & 3.12 & 25 & 200 \\
\hline$K p$ & 125 & 500 & 125 & 500 & 6.25 & 200 & 100 & 200 \\
\hline$E a$ & 31.2 & 125 & 62.5 & 250 & 1.56 & 12.5 & 200 & 200 \\
\hline$M n$ & 62.5 & 250 & 125 & - & 6.25 & 50 & 200 & 200 \\
\hline
\end{tabular}

Source: Authors (2021)

In where: (a) Antibiotics. (-) There was no inhibition at the tested concentration. GRAM +: Bs: Bacillus subtilis; Bc: Bacillus cereus; Ef: Enterococcus fecalis; Sa: Staphylococcus aureus; GRAM-: St: Salmonella enterica serovar Typhimurium; Sn: Salmonella enteritidis; Pm: Proteus mirabilis; Ec: Escherichia coli; Pa: Pseudomonas aeruginosa; Sf: Shigella flexneri; Ss: Shigella sonnei; Kp: Klebsiella pneumonia; Ea: Enterobacter aerogenes; Mm: Morganela morgani.

The extracts obtained exhibited significant inhibitory activity against all bacteria analyzed at $30^{\circ} \mathrm{C}$, and the MIC values for Gram-positive bacteria (Table 2) varied between $31.2 \mu \mathrm{g} \mathrm{mL}^{-1}$ (Staphylococcus aureus) and $62.5 \mathrm{\mu g} \mathrm{mL}^{-1}$ (Bacillus subtilis; Bacillus cereus; Enterococcus fecalis). As for the Gram-negative bacteria (Table 2), these values were between $31.2 \mathrm{\mu g} \mathrm{mL}^{-1}$ (Enterobacter aerogenes) and 250 
$\mu \mathrm{g} \mathrm{mL}^{-1}$ (Salmonella enterica serovar Typhimurium; Proteus mirabilis; Escherichia coli; Pseudomonas aeruginosa). For the extract at the temperature of $60^{\circ} \mathrm{C}$, the MIC values for the Gram-positive bacteria (Table 2) ranged from $62.5 \mu \mathrm{g} \mathrm{mL}^{-1}$ (Bacillus cereus; Enterococcus fecalis; Staphylococcus aureus) to $125 \mathrm{\mu g} \mathrm{mL}^{-1}$ (Bacillus subtilis). For the Gram-negative bacteria (Table 2), the values were between $62.5 \mu \mathrm{gL}^{-1}$ (Shigella flexneri; Enterobacter aerogenes) and $250 \mu \mathrm{g} \mathrm{mL}^{-1}$ (Salmonella enterica serovar Typhimurium; Proteus mirabilis; Escherichia coli; Pseudomonas aeruginosa). In both temperatures, the extracts showed antifungal potential (Table 3), with the temperature of $30^{\circ} \mathrm{C}$ inhibiting the growth of all fungi evaluated with MIC values of $62.5 \mu \mathrm{g} \mathrm{mL}^{-1}$ (Cryptococcus gatti; Cryptococcus neoformans) and $500 \mathrm{\mu g} \mathrm{mL}^{-1}$ (Candida glabrata; Candida krusei; Candida parapsilosis; Saccharomyces cerevisiae). For the extract at $60{ }^{\circ} \mathrm{C}$, the values ranged from $62.5 \mathrm{\mu g} \mathrm{mL}^{-1}$ (Cryptococcus gatti; Cryptococcus neoformans) to $500 \mathrm{\mu g} \mathrm{mL}^{-1}$ (Candida glabrata; Candida krusei; Candida parapsilosis; Candida tropicalis; Saccharomyces cerevisiae). The extracts also exhibited bactericidal potential (Table 2), and at $30^{\circ} \mathrm{C}$, the MLC was $125 \mu \mathrm{g} \mathrm{m}^{-1}$ for Bacillus subtilis and Enterobacter aerogenes. At $60{ }^{\circ} \mathrm{C}$, the MLC was $250 \mu \mathrm{g} \mathrm{mL}-1$ for Staphylococcus aureus and Enterobacter aerogenes. Regarding antifungal activity (Table 3), the minimum MLC value of the extract at $30{ }^{\circ} \mathrm{C}$ was $250 \mu \mathrm{gL}^{-1}$ and 500 $\mu \mathrm{g} \mathrm{mL} \mathrm{L}^{-1}$ at $60^{\circ} \mathrm{C}$. 
Table 3 - Antifungal activity (MIC and MLC in $\mu \mathrm{g} / \mathrm{mL}$ ) of the extracts obtained at 30 and $60^{\circ} \mathrm{C}$ from the Inga marginata Willd seeds

\begin{tabular}{|c|c|c|c|c|c|c|c|c|}
\hline \multirow{3}{*}{$\begin{array}{c}\text { Microorganism } \\
\text { and MIC/MLC } \\
(\mu \mathrm{g} / \mathrm{mL})\end{array}$} & \multicolumn{4}{|c|}{ Fungi } & \multicolumn{4}{|c|}{ Sample } \\
\hline & \multicolumn{2}{|c|}{ Seed $30^{\circ} \mathrm{C}$} & \multicolumn{2}{|c|}{ Seed $60^{\circ} \mathrm{C}$} & \multicolumn{2}{|c|}{ Fluconazole $^{a}$} & \multicolumn{2}{|c|}{ Nystatina $^{a}$} \\
\hline & MIC & MLC & MIC & MLC & MIC & MLC & MIC & MLC \\
\hline $\mathrm{Ca}$ & 250 & - & 250 & - & 25 & 100 & 50 & 100 \\
\hline$C d$ & 125 & - & 250 & - & 3.12 & 12.5 & 50 & 100 \\
\hline $\mathrm{Cl}$ & 500 & - & 500 & - & 3.12 & 200 & 50 & 100 \\
\hline$C k$ & 500 & - & 500 & - & 25 & 200 & 12.5 & 50 \\
\hline$C p$ & 500 & - & 500 & - & 1.56 & 25 & 1.56 & 100 \\
\hline$C t$ & 250 & - & 500 & - & 50 & 200 & 100 & 200 \\
\hline $\mathrm{Cg}$ & 62.5 & 500 & 62.5 & 500 & 3.12 & 25 & 25 & 100 \\
\hline $\mathrm{Cn}$ & 62.5 & 250 & 62.5 & 500 & 3.12 & 12.5 & 25 & 100 \\
\hline SC & 500 & - & 500 & - & 1.56 & 25 & 1.56 & 3.12 \\
\hline
\end{tabular}

Source: Authors (2021)

In where: ( $\left.{ }^{a}\right)$ Antibiotics. (-)There was no inhibition at the tested concentration. Ca: Candida albicans; $C d$ : Candida dubliniensis; Cl: Candida glabrata; Ck: Candida krusei; Cp: Candida parapsilosis; Ct: Candida tropicalis; Cg: Cryptococcus gatti; Cn: Cryptococcus neoformans; Sc: Saccharomyces cerevisiae.

Nascimento, Sobrinho, Souza, Souza, and Sousa (2021) analyzed Inga edulis leaves by solid-liquid extraction and reported that MIC ranged from 125 to $500 \mu \mathrm{g}$ $\mathrm{mL}^{-1}$ and from 12.5 to $200 \mu \mathrm{g} \mathrm{mL}^{-1}$ for Gram-negative and Gram-positive bacteria, respectively. Moreover, Macedo, Ribeiro, Taveira, Gomes, Barros, and Maria-Neto (2016) evaluated Inga laurina Willd seed extracts and noted that they significantly inhibited the growth of Candida tropicalis and Candida buinensis and the yeasts $C$. tropicalis and C. buinensis. The bacteria tested in this study can cause food spoilage, including physical damage and chemical changes, such as oxidation and color changes or the appearance of strange flavors and odors resulting from microbial growth and metabolism. There are several types of bacteria associated with the spoilage of fresh produce, and they are also toxic to human health. This demand could be met with the use of natural antimicrobials, that is, adding plant extracts 
with antimicrobial action to preserve food (ZHENG; BAE; JUNG; HEU; LEE, 2013). The antibacterial effects of phenolic compounds are mainly due to their chemical structure in hydroxyl groups in their molecules. In fact, the number and position of these hydroxyl groups (i.e., the hydroxylation pattern) on the phenolic ring seem to be associated with the inhibition exerted on the target fungal bacteria (SANHUEZA; MELO; MONTERO; MAISEY; MENDOZA; WILKENS, 2017).

\subsection{Characterization of Inga marginata Willd seed extract by ESI-ToF MS}

To characterize the compounds, only the extract obtained at $30^{\circ} \mathrm{C}$ was used, which exhibited high phenolic compound content, antioxidant capacity, and ability to inhibit microorganisms (Tables 2 and 3). The identification of the peaks was performed based on their exact mass, together with information previously reported in the literature, and the chemical structures were determined based on mass spectral data, and ten phytochemical compounds were identified (Table 4). Including neoesperidin dihydrocalcone, which has significant antioxidant properties and attracted increasing interest in recent years, exhibits a wide range of biological and antioxidant activities, such as anti-inflammatory and antimicrobial properties (FRATTARUOLO et al., 2019). Caffeic acid was also found, and several studies have proven its antibacterial, antiviral, antioxidant, anti-inflammatory, antiatherosclerotic, immunostimulatory, antidiabetic, and cardioprotective activities, in addition to being widely found in vegetables, especially fruits (ESPÍNDOLA et al., 2019). Additionally, Dias, Souza, and Rogez (2010) also reported finding procyanidins in Inga edulis leaves, and in addition to their antioxidant properties, these compounds have been reported to exhibit anticancer, anti-infective, cardioprotective, anti-inflammatory, and anti-allergic properties (MARTIN; GOYA; RAMOS, 2013).

Gerberinol is a still poorly investigated compound and was also found. In the study by Lenta (2015), the authors identified and isolated this compound in the 
stem bark of the $D$. canaliculata plant, which exhibits antiprotozoal activity in vitro. The amino acid L-valine has been identified as part of a group of amino acids known as branched-chain amino acids, namely L-leucine, L-isoleucine, and L-valine. Together, these proteins promote normal growth, regulate blood sugar levels, energize the body, and are crucial in tissue repair (CRUZAT; KRAUSE; NEWSHOLME, 2014). This compound was also found in a ginger extract in the study by Alolga, Mais, and Onoja (2017).

Table 4 - Characterization of phytochemical and chemical compounds in the Inga marginata Willd seed extract by ESI-ToF MS in positive and negative modes

\begin{tabular}{|c|c|c|c|c|c|c|}
\hline $\mathbf{N}^{\circ}$ & $\begin{array}{l}\text { Experimental } \\
\text { mass }(m / z)\end{array}$ & $\begin{array}{l}\text { Theoretical } \\
\text { mass }(\mathrm{m} / \mathrm{z})\end{array}$ & $\begin{array}{l}\text { Pure } \\
\text { error } \\
(\mathrm{ppm})\end{array}$ & $\begin{array}{l}\text { Possible } \\
\text { molecular } \\
\text { structure }\end{array}$ & Compounds & Reference \\
\hline \multirow[t]{2}{*}{1} & 543.1331 & 543.1350 & 2 & $\mathrm{C}_{23} \mathrm{H}_{26} \mathrm{O}_{15}$ & Neohesperidin & (HU et al., 2014) \\
\hline & & & & & Dihydrochalcone & \\
\hline 2 & 377.0854 & 377.0873 & 1 & $\mathrm{C}_{18} \mathrm{H}_{18} \mathrm{O}_{9}$ & Caffeic Acid & (TOTH; TOTH; KERY, 2014) \\
\hline 3 & 364.3480 & 364.34800 & 6 & $\mathrm{C}_{21} \mathrm{H}_{16} \mathrm{O}_{6}$ & Gerberinol & (LENTA et al., 2015) \\
\hline 4 & 325.1128 & 325.1128 & 0.6 & $\mathrm{C}_{5} \mathrm{H}_{11} \mathrm{NO}_{2}$ & L-Valine & (ALOLGA; MAIS; ONOJA, 2017) \\
\hline \multirow[t]{3}{*}{5} & 381.0803 & 381.0803 & 4 & $\mathrm{C}_{17} \mathrm{H}_{16} \mathrm{O}_{10}$ & 8-Hydroxy-5-O-beta-D- & (XIAO; LI; MASAHIKO, 2001) \\
\hline & & & & & glucopyranosylpsorale & \\
\hline & & & & & $\mathrm{n}$ & \\
\hline \multirow[t]{2}{*}{6} & 277.1661 & 277.1661 & 3.6 & $\mathrm{C}_{13} \mathrm{H}_{25} \mathrm{O}_{6}$ & 15a-Butoxy-14,15- & (GAN; YUE, 2006) \\
\hline & & & & & dihydronorsecurinine & \\
\hline \multirow[t]{3}{*}{7} & 307.1767 & 307.1767 & 2.9 & $\mathrm{C}_{17} \mathrm{H}_{25} \mathrm{NO}_{4}$ & Alkaloid & (KAKUTA; HITOTSUYANAGI; \\
\hline & & & & & (sessilifoliamide A) & MATSUURA; FUKAYA;TAKEYA, \\
\hline & & & & & & 2003) \\
\hline 8 & 191.0205 & 191.0192 & 6.8 & $\mathrm{C}_{6} \mathrm{H}_{8} \mathrm{O}_{7}$ & Citric acid & (WILLIAM et al., 2018) \\
\hline \multirow[t]{3}{*}{9} & 381.0803 & 381.822 & 3 & $\mathrm{C}_{17} \mathrm{H}_{16} \mathrm{O}_{10}$ & 6-O- $\beta-D-$ & (CHANG et al., 2005) \\
\hline & & & & & Glucopyranosyl-5- & \\
\hline & & & & & hydroxyangelicin & \\
\hline 10 & 577.1373 & 577.1405 & 5.5 & $\mathrm{C}_{23} \mathrm{H}_{30} \mathrm{O}_{17}$ & Procyanidins & (WILLIAN et al., 2018) \\
\hline
\end{tabular}

Source: Authors (2021)

In where: *m/z: ratio mass $(\mathrm{m})$ over charge $(\mathrm{z})$. 
The compound 8-Hydroxy-5-O-beta-D-glucopyranosylpsoralen belongs to glycoside molecules and is widely distributed in the plant kingdom. These compounds are known for their anti-cancer and anti-inflammatory properties due to their affinity for proteins and their antioxidant properties (BIESAGA; PYRZYNSKA, 2009). Lima, Andrade, and Silva (2020) reported this glycoside in the extracts of Inga edulis leaves. The compounds 15a-Butoxy-14,15-dihydronorsecurinine and sessilifoliamide were also identified; they are considered alkaloid compounds. The pharmacological benefits of alkaloids are well known, such as activity in the circulatory system, metabolism against obesity, and cardiac dysfunction (e.g., antioxidant, anticancer, and neuroprotective properties), and often found in seeds and plant extracts (ROMEO; FABRONI; BALLISTRERI; MUCCILLI; SPINA; RAPISARDA, 2018).

Citric acid was also identified, and it is a known natural preservative and antioxidant (WILLIAM et al., 2018). This compound can be found in acidic fruits, especially in their residues (AYDOGAN; KARAKOÇ; DENIZLI, 2015). The compound 6-O- $\beta$-D-Glucopyranosyl-5-hydroxyangelicin is also present in the extract, and Chang et al., (2005) reported this compound in the leaf extracts of Ficus ruficaulis Merr, a Chinese medicinal plant, and reported antioxidant and anti-inflammatory action.

Thus, the characterization by ESI-ToF-MS allowed important phytochemicals of industrial interest to be identified. Most of the compounds identified are antioxidant compounds. Therefore, it can be said that the antibacterial and antifungal effects (Tables 2 and 3) observed in the Inga extract are directly associated with their phytochemical composition. Synergism and molecular antagonism may exist in the composition of fruit or extract, although further research is required to explore the endointeractions within a specific food or extract (FREEMAN; EGGETT; PARKER, 2010). In these cases, some compounds or only a major compound can be extracted from the fruit or vegetable parts (GORGANI; MOHAMMADI; NAJAFPOUR; NIKZAD, 2016). 


\subsection{Inga seed cytotoxicity}

Cytotoxicity analysis has the main objective of detecting the potential of a sample to produce lethal or sublethal effects in biological systems at the cellular level. This assay is characterized as the intrinsic ability of any material or compound to promote metabolic changes in cultured cells. Cytotoxicity assays are among the most common in vitro methods used to predict the potential toxicity of a substance in cell cultures (ROGERO; LUGÃO; IKEDA; CRUZ, 2003). Therefore, we evaluated the cytotoxicity of the lyophilized sample of Inga seed at different concentrations by the MTT and NRU tests in the period of $24 \mathrm{~h}$ using $3 T 3$ cell viability. The results were expressed as a percentage of viability in relation to control the cells, which have $100 \%$ viability (Figure 2 ).

Figure 2 - Evaluation of the cytotoxic activity of Inga seeds by the MTT and NRU viability tests for $24 \mathrm{~h}$ at different concentrations of the sample
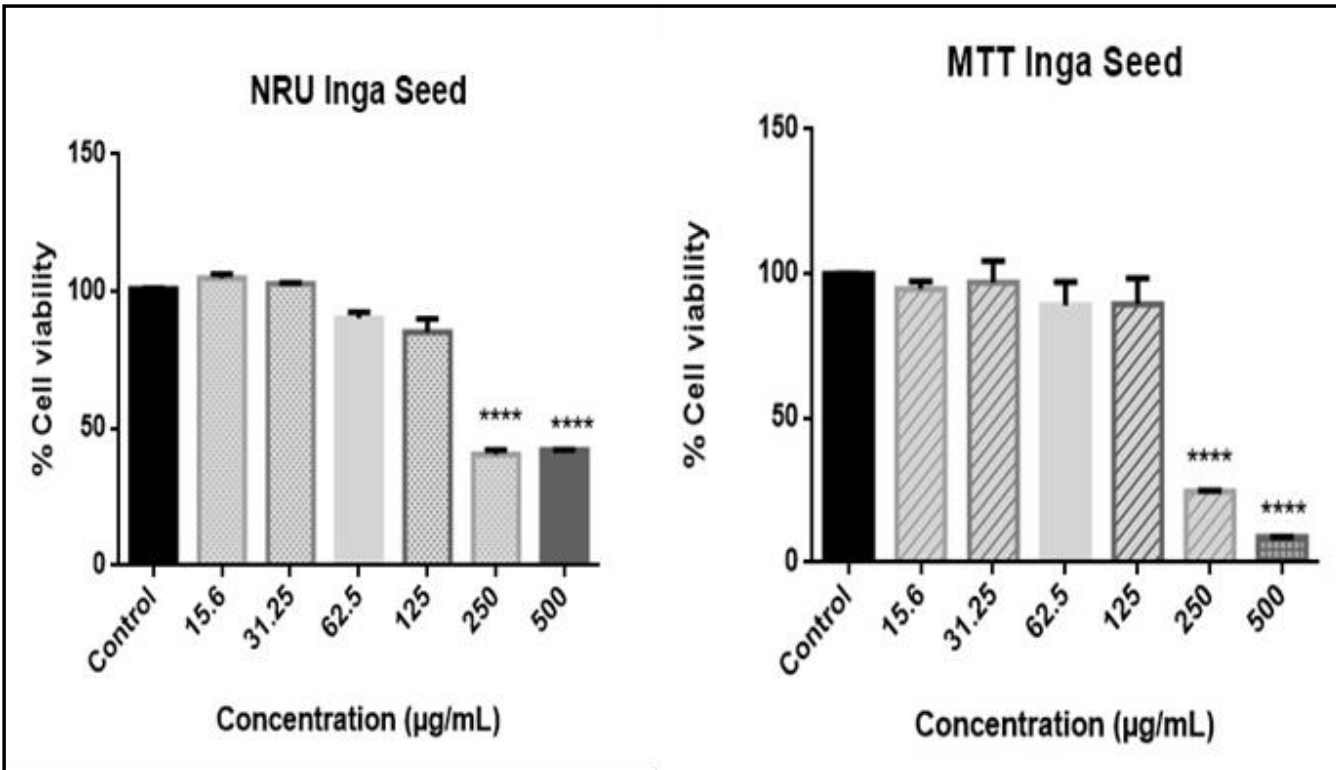

Source: Authors (2021)

In where: Viability plots in 3 T3 cell line exposed to different concentrations of sample by MTT and NRU tests. Control (untreated) cells at $100 \%$ viability considering there is significant difference when a $p<0.05$ level is reached $(*) p<0.05 /(* * * *) p<0.0001$. Samples with standard deviation.

Our findings showed that the Inga seed has cytotoxic activity only at the concentration of $250 \mu \mathrm{g} \mathrm{mL}^{-1}$ for both the cell viability tests by 2,5-diphenyl-3-(4,5- 
dimethyl-2-thiazolyl) tetrazolium bromide (MTT) and Neutral Red Uptake (NRU), differing statistically compared to the control 250 and $500 \mu \mathrm{gL}^{-1}(p<0.0001)$. In the MTT test and at low concentrations $\left(15.6,31.25,62.5\right.$, and $\left.125 \mu \mathrm{g} \mathrm{m}^{-1}\right)$, cell viability of $94,97,89$, and $90 \%$ were obtained, respectively, with no statistically significant difference at these concentrations compared to the control, being considered non-cytotoxic because cell viability was greater than 90\% (LOPES; FASCIO, 2004). For the NRU test, the sample was also non-cytotoxic at the concentrations of $15.6,31.25,62.5$, and $125 \mathrm{~g} \mathrm{~mL}^{-1}$, obtaining cell viability of 100 , 99,92 , and $90 \%$, respectively, with no statistically significant difference at these concentrations compared to the control. Fruit seeds can contain toxic substances, including tannins, acids, glycosides, and cyanogenic phenolics with high cyanide content. Hence, when the seeds undergo breakage or maceration, the content of the compounds change, and toxic substances are produced, which can be explained by the fact that plant-defense substances are released (SENICA; STAMPAR; VEBERIC; MIKULIC-PETKOVSEK, 2017).

\section{CONCLUSION}

This study brought evidence that the plant material under study, the Inga marginata Willd seed extract, has a potent phytochemical action since $30^{\circ} \mathrm{C}$ was the best condition to extract phenolic compounds and for antioxidant activity by DPPH and inhibitory capacity $\left(\mathrm{IC}_{50}\right)$, obtaining better results at this temperature than at $60{ }^{\circ} \mathrm{C}$. The Inga seed extract obtained at $30{ }^{\circ} \mathrm{C}$ also inhibited microorganisms and acted as a bactericide and fungicide at low concentrations. In addition, it was possible to identify ten phytochemical compounds, most of which have antioxidant and antimicrobial properties. The cytotoxicity tests showed that the Inga seed does not present toxicity at low concentrations, maintaining cell viability above $90 \%$. Given all these bioactive benefits, the use of Inga marginata 
Willd seeds as an extract is of great importance, as it can be considered a natural source of compounds that have antioxidant and antimicrobial effects.

\section{ACKNOWLEDGMENTS}

The authors would like to thank the Department of Food Science and Technology (Federal University of Santa Maria, RS, Brazil). This study was partially funded by Coordenação de Aperfeiçoamento de Pessoal de Nível Superior (CAPES) Financial Code 001. The authors would also like to thank Atlas Assessoria Linguística for providing support with the English version of this manuscript.

\section{REFERENCES}

ALARA, O.; ABDURAHMAN, R.; UKAEGBU, N.H. Extraction of phenolic compounds: A review. Current Research in Food Science, v.4, p.200-214, 2021.

ALOLGA, R.N.; MAIS, E.; ONOJA, V. A comparative anti-inflammatory evaluation of fresh ginger extracts from China and Ghana identifies L-valine as a diagnostic biomarker. African Journal of Pharmacy and Pharmacology, v. 12, n. 47, p. 582-590, 2017.

AQIL, F. et al. Anti-proliferative activity and protection against oxidative DNA damage by punicalagin isolated from pomegranate husk. Food Research International, v.49, n.1, p. 345353, 2012.

AYDOGAN, C.; KARAKOÇ, V.; EDENIZLI, A. 2015. Chiral ligand-exchange separation and determination of malic enantiomers im apple juice by open-tubular capillary electrochomatography. Food Chemistry, v.187, p. 130-134, 2015.

BEDNARCZUK, V.O.; VERDAM, M.C.S.; MIGUEL, M.D.; MIGUEL, O.G. Testes in vitro e in vivo utilizados na triagem toxicológica de produtos naturais. Visão Acadêmica, v.11, n.2, p. 43-50, 2010.

BIESAGA, M.; PYRZYNSKA, K. Analytical Procedures for Determination of Quercetin and its Glycosides in Plant Material. Critical Reviews in Analytical Chemistry, v.39, n.2, p.95-107, 2009.

BIZZI, C.A. et al. Furfural Production from Lignocellulosic Biomass by Ultrasound-assisted Acid Hydrolysis. Ultrasonics Sonochemistry, v. 51, p. 332-339, 2019. 
BRAND-WILLIAMS, W.; CUVELIER, M.E.; BERSET, C. Use of a free radical method to evaluate antioxidant activity. Food Science and Technology, v.28, n.1, p. 25-30, 1995.

CHANG, M.S. et al. Furocoumarin glycosides from the leaves of Ficus ruficaulis Merr. var. antaoensis. Journal of Natural Products, v.68, n.1, p.11-3, 2005.

CRUZAT, V.F.; KRAUSE M.; NEWSHOLME, P. Amino acid supplementation and impact on immune function in the context of exercise. J. Int. Soc.Sport Nutr. v.11, n.1, p.61, 2014.

DAl, J.; MUMPER, R.J. Plant phenolics: Extraction, analysis and their antioxidant and anticancer properties (Review). Molecules, v.15, n.10, p. 7313-7352, 2010.

DIAS, A. L. S.; SOUZA, J. N. S.; ROGEZ, H. Enriquecimento de compostos fenólicos de folhas de Inga edulis por extração em fase sólida: Quantificação de seus compostos majoritários e avaliação da capacidade antioxidante. Química Nova, v.33, n.1, p. 38- 42, 2010.

DJIKENG, F.T. et al. Effect of traditional and oven roasting on the physicochemical properties of fermented cocoa beans. Heliyon, v.4. n.2, e00533, 2018.

ESPÍNDOLA, K.M.M. et al. Chemical and Pharmacological Aspects of Caffeic Acid and Its Activity in Hepatocarcinoma. Frontiers in Oncology, v. 9, p. 541, 2019.

FRATTARUOLO, L. et al. Antioxidant and Anti-Inflammatory Activities of Flavanones from Glycyrrhiza glabra L. (licorice) Leaf Phytocomplexes: Identification of Licoflavanone as a Modulator of NF-kB/MAPK Pathway. Antioxidants, v.8, n.6, p. 186, 2019.

FREEMAN, B.L.; EGGETT, D.L.; PARKER, T.L. Synergistic and Antagonistic Interactions of Phenolic Compounds Found in Navel Oranges. Journal of food science, v.75, n.6, p.C570-C576, 2010.

GAN, L-S.; YUE J-M. Alkaloids from the Root of Flueggea Virosa. Natural Product Communications, v.1, n.10, p.819-823, 2006.

GORGANI, L.; MOHAMMADI, M.; NAJAFPOUR, G.D.; NIKZAD, M. Piperine-The Bioactive Compound of Black Pepper: From Isolation to Medicinal Formulations. Comprehensive Reviewsin Food Science and Food Safety, v.16, n.1, p. 124-140, 2017.

HARUNA, A.; YAHAYA, S.M. Recent Advances in the Chemistry of Bioactive Compounds from Plants and Soil Microbes: a Review. Chemistry Africa, v. 4, p.231-248, 2021.

HU, L. et al. Protective effects of neohesperidin dihydrochalcone against carbon tetrachlorideinduced oxidative damage in vivo and in vitro. Chemico-Biological Interactions, v. 213, p.5159, 2014.

KAKUTA, D.; HITOTSUYANAGI, Y.; MATSUURA, N.; FUKAYA, H.; TAKEYA, K. Structures of new alkaloids sessilifoliamides A-D from Stemona sessilifolia. Tetrahedron, v.59, n.39, p. 7779-7786, 2003. 
KOOLEN, H. H. F.; SILVA, F. M. A.; GOZZO, F. C.; SOUZA, A. Q. L.; SOUZA, A. D. L. Antioxidant, antimicrobial activities and characterization of phenolic compounds from buriti (Mauritia flexuosa L. f.) by UPLC-ESI-MS/MS. Food Research International, v.51, n.2, p. 467- 473, 2013.

LENTA, B.N. et al. Compounds from Diospyros canaliculata (Ebenaceae) and their Antiparasitic Activities. International Research Journal of Pure and Applied Chemistry, v.6, n.2, p. 56-65, 2015.

LIAZID, A.; PALMA, M.; BRIGUI, J.; BARROSO, C.G. Investigation on phenolic compounds stability during microwave-assisted extraction. Journal of Chromatography A, v.1140, n.1-2, p.29-34, 2007.

LIMA, N. M.; SANTOS, V. N. C.; LA PORTA, F. A. Quimiodiversidade, Bioatividade e Quimiossistemática do Gênero Inga (FABACEAE): Uma Breve Revisão. Revista Virtual Química, v.10, n. 3, p. 459-473, 2018.

LIMA, N.M.; ANDRADE, T.J.A.S.; SILVA, D.H.S. Dereplication of terpenes and phenolic compounds from Inga edulis extracts using HPLC-SPE-TT, RP-HPLC-PDA and NMR spectroscopy. Nat Prod Res., v. 2, p.1-5, 2020.

LOKVAM, J.; COLEY, P.D.; KURSAR, T.A. Cinnamoyl glucosides of catechin and dimeric procyanidins from young leaves of Inga umbellifera (Fabaceae). Phytochemistry, v.65, n.3, p. 351-358, 2004.

LOPES, W. A.; FASCIO, M. Esquema para interpretação de espectros de substâncias orgânicas na região do infravermelho. Química Nova, v. 27, n. 4, p. 670-673, 2004.

MACEDO, M.L.R.; RIBEIRO, S.F.F.; TAVEIRA, G.B.; GOMES, V.M.; BARROS, K.M.C.A.DE.; MARIANETO, S. Antimicrobial Activity of ILTI, a Kunitz-Type Trypsin Inhibitor from Inga laurina Willd. Current Microbiology, v.72, p.538-544, 2016.

MARTIN, M.A.; GOYA, L.; RAMOS, S.Potential for preventive effects of cocoa and cocoa polyphenols in cancer. Food Chemistry Toxicologic, v. 56, p.336-351, 2013.

MENDOZA, N.A.S.; MARTÍNEZ, C.J.; MARTÍNEZ, A.C.; BARBA, S.M.DE.C.; ORTIZ, G.D.

Physical, nutritional and non nutritional characterization of Inga paterno seeds. Chilean magazine of nutrition, v.43, n.4, p. 400-407, 2016.

MUNIR, A. et al. Evaluation of Antioxidant Potential of Vegetables Waste. Polish Journal of Environmental Studies, v.27, n. 2, p.947-952, 2018.

NASCIMENTO, V.H.A. DO.; SOBRINHO, A.C.G.; SOUZA, C.DE. O.; SOUZA, J.N.S.DE.; SOUSA, C.L. Determination of Phenolic Compounds with Antimicrobial Activity of Byrsonima Crassifolia and Inga Edulis Leaves Extracts. Essays and Science, v.25, n.1, p.21-28, 2021. 
National Committee for Clinical Laboratory Standards, NCCL. Reference method for broth dilution antifungal susceptibility testing of yeast: approved standard. National Committee for Clinical Laboratory Standards, Wayne, PA. CLSI document M27eA2, 2017.

National Committee for Clinical Laboratory Standards, NCCL. Methods for dilution antimicrobial susceptibility tests for bacteria that grow aerobically: approved standard, 11 th ed. National Committee for Clinical Laboratory Standards, Wayne, PA. CLSI document M07eA5, 2018.

NEGRELLE, R.R.B.; GOMES, E.C. Cymbopogon citratus (D.C) Stapf: chemical composition and biological activities. Revista Brasileira de Plantas Medicinais, v.9, n.1, p.80-92, 2007.

PIOVESAN, N. et al. Microwave-assisted extraction of bioactive compounds from blueberry (Vaccinium ashei Reade) and their antioxidant and antimicrobial capacity. International Food Research Journal, v.24, n.6, p. 2526-2533, 2017.

POSSETTE, R. F. S.; RODRIGUES, W. A. O gênero Inga Mill. (Leguminosae-Mimosoideae) no estado do Paraná, Brasil. Acta Botanica Brasílica, v. 24, n.2, p.354-368, 2010.

ROESLER, R.; MALTA, L.G.; CARRASCO, L.C.; HOLANDA, R.B.; SOUSA, C.A.S.; PASTORE, G.M. 2007. Antioxidant activity of cerrado fruits. Food Science and Technology, v.27, p.53-60.

ROGERO, S.O.; LUGÃO, A.B.; IKEDA T.I.; CRUZ, À.S. In vitro cytotoxicity test: comparative study between two methodologies. Materials Research, v.6, n.3, p. 317-320, 2003.

ROMEO, F.V.; FABRONI, S.; BALLISTRERI, G.; MUCCILLI, S.; SPINA A.; RAPISARDA, P. Characterization and Antimicrobial Activity of Alkaloid Extracts from Seeds of Different Genotypes of Lupinus spp. Sustainability, v.10, n.3, 788, 2018.

SANHUEZA, L.; MELO,R.; MONTERO, R.; MAISEY, K.; MENDOZA, L.; WILKENS, M. 2017. Synergistic interactions between phenolic compounds identified in grape pomace extract with antibiotics of different classes against Staphylococcus aureus and Escherichia coli. PLoS One, v.12, n.2, e0172273.

SCALBERT, A.; JOHNSON, I.T.; SALTMARSH, M. Polyphenols: antioxidants and beyond. The American Journal of Clinical Nutrition, v. 81, n. 1, p. 215S-217S, 2005.

SENICA M.; STAMPAR F.; VEBERIC, R.; MIKULIC-PETKOVSEK, M. Fruit Seeds of the Rosaceae Family: A Waste, New Life, or a Danger to Human Health?. Journal of Agricultural and Food Chemistry, v.65, n.48, p.10621-10629, 2017.

SILVA, E.M.; ROGEZ, H.; LARONDELLE, Y. Optimization of extraction of phenolics from Inga edulis leaves using response surface methodology. Separation and Purification Technology, v.55, n.3, p. 381-387, 2007. 
SUHAIL, N. et al. Effect of vitamins $C$ and $E$ on antioxidant status of breast-cancer patients undergoing chemotherapy. Journal of Clinical Pharmacy and Therapeutics, v.37, p. 22-26, 2012.

TANASE, C. et al. Biological and chemical insights of beech (Fagus sylvatica l.) bark: A source of bioactive compounds with functional properties (Article). Antioxidants, v.8, n.9, p.417, 2019.

TCHUENMOGNE, A.M.T. et al. A new flavonol and other chemical constituents from leaves and stem bark of inga edulis mart. Bulletin of the Korean Chemical Society, v,34, n.12, p. 38593862, 2013.

TOTH, A.; TOTH, G.; E KERY, A. Polyphenol Composition and Antioxidant Capacity of Three Lysimachia Species. Natural Product Communications, v.9, n. 10, 2014.

VICTORIO, C. P.; LAGE, C. L. S.; KUSTER, R. M. Flavonoids extraction from Alpinia zerumbet (Pers.) Burtt et Smith leaves using different procedures. Eclética Química, v.35, n.1, p.35-40, 2010.

WILLIAM, J. et al. Antioxidant activity, Hypoglycemic potential and metabolite profiling of Hyophorbe indica leaf extract. Pakistan Journal of Pharmaceutical Sciences, v.31, n. 6, p.27372742, 2018.

XIAO, Y.Q.; LI, L.; MASAHIKO, T. Glucosides from Pleurospermum rivulorum]. National Library of Medicine, v.36, n.7, p.519-22, 2001.

XU, L.; MENG, W.; CAO, C.; WANG, J.; SHAN, W.; WANG, Q. Antibacterial and antifungal compounds from marine fungi (Review). Marine Drugs, v.13, n.6, p. 3479-3513. 2015.

ZHENG, L.; BAE, Y-M.; JUNG, K.S.; HEU, S.; LEE, S-Y. Antimicrobial activity of natural antimicrobial substances against spoilage bacteria isolated from fresh produce. Food Control, v.32, n.2, p.665-672, 2013.

\section{Authorship contributions}

\section{1 - Déborah Cristina Barcelos Flores}

Master in Science and Technology in Food https://orcid.org/0000-0003-1674-5210 - deborahbflores@gmail.com Contribution: Conceptualization, Data Curation, Formal Analysis, Investigation, Writing - Original Draft, Writing - Review \& Editing

\section{2 - Caroline Pagnossim Boeira}

Master in Science and Technology in Food https://orcid.org/0000-0003-1674-5210 - carolinepagnossim@hotmail.com Contribution: Formal Analysis, Methodology, Software, Visualization 


\section{3 - Clarice Madalena Bueno Rolim}

PhD in Pharmaceutical Science and Technology, Professor https://orcid.org/0000-0002-9634-8970 - clarice.rolim@gmail.com

Contribution: Methodology, Validation, Data Curation

\section{4 - Daniele Rubert Nogueira Librelotto}

PhD em Research, Development and Control of Medicines, Professor https://orcid.org/0000-0003-0570-5555 - daniele.rubert@gmail.com Contribution: Methodology, Validation, Data Curation

\section{5 - Frederico Luiz Reis}

Master in Organic Chemistry

https://orcid.org/0000-0001-5269-337X - reis.fredericoreis@gmail.com Contribution: Conceptualization, Funding Acquisition, Methodology

\section{6 - Liziane Maria Barassuol Morandini}

PhD in Chemistry, Professor https://orcid.org/0000-0001-8257-8444 - lizianemorandini@gmail.com Contribution: Conceptualization, Funding Acquisition, Methodology

\section{7 - Ademir Farias Morel}

PhD in Chemistry, Professor https://orcid.org/0000-0003-3536-2418 - ademirfariasm@gmail.com Contribution: Conceptualization, Funding Acquisition, Methodology

\section{8 - Claudia Severo da Rosa}

$\mathrm{PhD}$ in Food Science, Professor

https://orcid.org/0000-0001-6931-7741 - claudiasr37@yahoo.com.br

Contribution: Conceptualization, Formal Analysis, Project Administration, Supervision

\section{How to quote this article}

FLORES, D.C.B.; BOEIRA, C.P.; ROLIM, C.M.B.; LIBRELOTTO, D.R.N.; REIS, F.L.; MORANDINI, L.M.B.; MOREL, A.F.; ROSA, C.S.. Phenolic compounds, antimicrobial activity, cytotoxicity and identification of phytochemicals present in Inga marginata Willd seeds. Ciência e Natura, Santa Maria, v. 43, e78, p. 1-25, 2021. Available in: https://doi.org/10.5902/2179460X65941. 